\title{
FACTORS ASSOCIATED WITH UNSAFE BEHAVIOR AMONG CONSTRUCTION WORKERS IN KUPANG, EAST NUSA TENGGARA
}

\author{
Noorce Christiani Berek
}

Faculty of Public Health, Universitas Nusa Cendana

\begin{abstract}
Background: Earlier studies have shown that about 90\% of accidents in the work settings occur because of unsafe behavior and human errors. If workers do not have the right knowledge, favorable attitude, and proper behavior toward safety measures in a safe workplace, all efforts for an accident-free workplace will be in vain. This study aimed to determine factors associated with unsafe occupational behavior among construction workers in Kupang, East Nusa Tenggara.

Subjects and Method: This was a cross sectional study carried out in Kupang, East Nusa Tenggara. A sample of 200 construction workers were selected at random for this study. The endogenous variables were perceive benefit, favorable attitude, and unsafe occupational behavior. The exogenous was good knowledge. The data were collected by questionnaire and analyzed by a path analysis model.

Results: Good knowledge increased perceived benefit $(b=0.25 ; 95 \% \mathrm{CI}=0.06$ to $0.56 ; \mathrm{p}=0.038)$. Perceived benefit increased favorable attitude $(\mathrm{b}=0.56 ; 95 \% \mathrm{CI}=$ 0.25 to $0.86 ; \mathrm{p}<0.001)$. Favorable attitude decreased unsafe occupational behavior ( $b=-0.56 ; 95 \% \mathrm{CI}=-0.32$ to $-0.80 ; \mathrm{p}<0.001$ ).

Conclusion: Good knowledge, perceived benefit, and favorable attitude, respectively, decrease unsafe behavior among the construction workers in the work settings.
\end{abstract}

Keywords: good knowledge, perceived benefit, favorable attitude, respectively, unsafe behavior, construction workers.

\section{Correspondence:}

Noorce Christiani Berek. Faculty of Public Health, Universitas Nusa Cendana, Jl. Adi Sucipto, Penfui, Kupang 8500o, East Nusa Tenggara.

Email: noorce.berek@staf.undana.ac.id. Mobile: 081228521127

The 4th International Conference on Public Health

Best Western Premier Hotel, Solo, Indonesia, August 29-30, 2018 | 75

https://doi.org/10.26911/theicph.2018.01.36 